Article

\title{
Sphaerostilbellins, New Antimicrobial Aminolipopeptide Peptaibiotics from Sphaerostilbella toxica
}

\author{
Bruno Perlatti ${ }^{1}{ }^{1}$, Connie B. Nichols ${ }^{2}$, J. Andrew Alspaugh ${ }^{2}{ }^{\circledR}$, James B. Gloer ${ }^{3}$ and \\ Gerald F. Bills ${ }^{1, *(\mathbb{D})}$ \\ 1 Texas Therapeutic Institute, The Brown Foundation Institute of Molecular Medicine, University of Texas \\ Health Science Center at Houston, Houston, TX 77054, USA; Bruno.Perlatti@uth.tmc.edu \\ 2 Departments of Medicine and Molecular Genetics \& Microbiology, Duke University Medical Center, \\ Durham, NC 27710, USA; connie.nichols@duke.edu (C.B.N.); andrew.alspaugh@duke.edu (J.A.A.) \\ 3 Department of Chemistry, University of Iowa, Iowa City, IA 52242, USA; james-gloer@uiowa.edu \\ * Correspondence: billsge@vt.edu
}

Received: 3 September 2020; Accepted: 25 September 2020; Published: 26 September 2020

\begin{abstract}
Sphaerostilbella toxica is a mycoparasitic fungus that can be found parasitizing wood-decay basidiomycetes in the southern USA. Organic solvent extracts of fermented strains of S. toxica exhibited potent antimicrobial activity, including potent growth inhibition of human pathogenic yeasts Candida albicans and Cryptococcus neoformans, the respiratory pathogenic fungus Aspergillus fumigatus, and the Gram-positive bacterium Staphylococcus aureus. Bioassay-guided separations led to the purification and structure elucidation of new peptaibiotics designated as sphaerostilbellins A and B. Their structures were established mainly by analysis of NMR and HRMS data, verification of amino acid composition by Marfey's method, and by comparison with published data of known compounds. They incorporate intriguing structural features, including an N-terminal 2-methyl-3-oxo-tetradecanoyl (MOTDA) residue and a C-terminal putrescine residue. The minimal inhibitory concentrations for sphaerostilbellins $\mathrm{A}$ and B were measured as $2 \mu \mathrm{M}$ each for $C$. neoformans, $1 \mu \mathrm{M}$ each for A. fumigatus, and 4 and $2 \mu \mathrm{M}$, respectively, for C. albicans. Murine macrophage cells were unaffected at these concentrations.
\end{abstract}

Keywords: antifungals; Hypocreaceae; mycoparasite; nonribosomal peptide; putrescine; secondary metabolite

\section{Introduction}

Cryptococcus species are among the most common causes of invasive fungal infections globally. Cryptococcus neoformans and C. gattii most often cause disease in people with compromised immune function. An estimated 220,000 cases of cryptococcosis occur annually, with mortality rates for patients with cryptococcal meningitis ranging from 10 to $70 \%$ [1,2]. As many as a third of all HIV/AIDS-associated deaths are due to cryptococcal disease, surpassing the number due to tuberculosis. Current treatments are limited to few antifungal agents (amphotericin B, flucytosine, fluconazole), with no new therapies introduced in recent decades. These therapeutics remain unsatisfactory because of their toxicity, inability to reliably eradicate the fungal pathogen and the emergence of drug resistance [3,4]. Even when treated, cryptococcosis is further complicated by high recurrence rates and the need for long-term suppressive therapy. Furthermore, the few antifungal agents currently in clinical development have not been chosen based on effectiveness against Cryptococcus [4,5]. As basidiomycetes, Cryptococcus species potentially offer unique biological perspectives to antifungal drug development compared to 
more broadly investigated ascomycete pathogens such as Candida and Aspergillus species. We have continued to screen metabolite-enriched fermentation extracts from unstudied ascomycete fungi and have tested these extracts in a growth-inhibition assay against the clinical strain C. neoformans H99 with the objective of identifying metabolites that inhibit its growth in vitro [6,7].

Recently, we have cultured, fermented, and tested extracts of a new species, Sphaerostilbella toxica, a fungus we have found parasitizing wood-decay basidiomycetes, e.g., Gloeophyllum striatum, in Texas (Figure 1) and Phellinus gilvus in North Carolina, USA [8]. Organic solvent extracts of cultures of this mycoparasite exhibited potent antimicrobial activity, including potent growth inhibition of C. neoformans. Sphaerostilbella toxica belongs to the Hypocreaceae, a family of ascomycetes that is dominated by species that are aggressive necrotrophic or biotrophic parasites of other fungi [9]. Besides species of Sphaerostilbella [8], the family Hypocreaceae includes well known mycoparasitic (also known as fungicolous) genera, e.g., Trichoderma, Hypomyces, and Escovopsis [9-11]. All fungi in this family studied to date have been shown to have a complex secondary metabolism which in part contributes to their capacity to invade, kill, and colonize other fungi [12-15]. The most consistently found class of natural products of these fungi are peptaibiotics, including peptaibols, that mediate their mycoparasite life style [16-19].

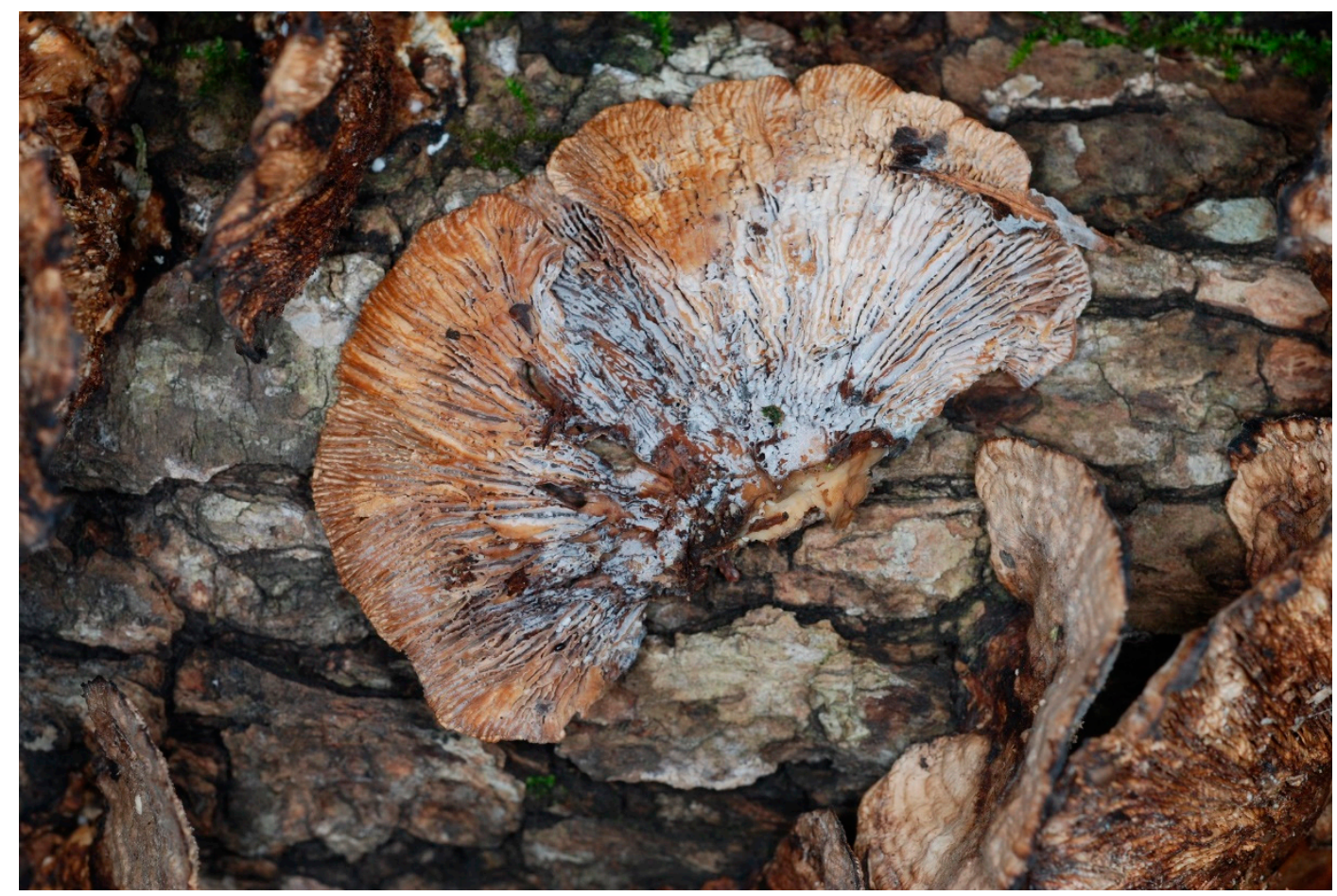

Figure 1. White superficial mycelium and conidia of Sphaerostilbella toxica parasitizing the lamellae of Gloeophyllum striatum. The type collection DPL-12808 (=NRRL 66954), from near Bleakwood (TX, USA), Texas. Photo by David P. Lewis.

Herein, we provide details on the fermentation of $S$. toxica leading to the bioactivity-guided purification and structure elucidation of new peptaibiotics with an unusual N-terminal fatty acid and C-terminal putrescine residue. Furthermore, we explored the antifungal spectrum of these new peptaibiotics. 


\section{Materials and Methods}

\subsection{Fermentation of Strains}

Strains TTI-0467 (=NRRL 66953) and DPL-12808 (=NRRL 66954) of S. toxica from Texas, USA have been described previously [8]. Strain TTI-1079 was isolated from mycelium colonizing the basidioma of Phellinus gilvus collected in Raleigh, NC, USA.

To make organic extracts for antimicrobial assays, strains TTI-0467, DPL-12808, and TTI-1079 were grown on five media in 12-mL fermentations. For the seed cultures, cryopreserved agar plugs were grown for 7 days in YM agar plates (10.0 g malt extract, $2.0 \mathrm{~g}$ yeast extract, and $20.0 \mathrm{~g}$ agar in $1000 \mathrm{~mL}$ deionized $\mathrm{H}_{2} \mathrm{O}$ ). Six agar discs from each culture were inoculated into $50 \mathrm{~mL}$ of SMY medium (40.0 g maltose, $10.0 \mathrm{~g}$ neopeptone, $10.0 \mathrm{~g}$ yeast extract, $3 \mathrm{~g}$ agar, $1000 \mathrm{~mL}$ deionized $\mathrm{H}_{2} \mathrm{O}$ ) in a 250-mL baffled flask. Seed cultures were grown at $24{ }^{\circ} \mathrm{C}, 220 \mathrm{rpm}$ for 4 days. One-mL aliquots of the seed cultures were transferred to 50-mL EPA glass vials containing $12 \mathrm{~mL}$ of the following media: for strain TTI-0467, the media set used Wheat 1 (5.0 g whole wheat seeds, $8.5 \mathrm{~mL}$ of base liquid consisting of yeast extract $2.0 \mathrm{~g}$, sodium tartrate $10.0 \mathrm{~g}, \mathrm{KH}_{2} \mathrm{PO}_{4} 1.0 \mathrm{~g}, \mathrm{MgSO}_{4} .7 \mathrm{H}_{2} \mathrm{O} 1.0 \mathrm{~g}, \mathrm{FeSO}_{4} .7 \mathrm{H}_{2} \mathrm{O} 0.050 \mathrm{~g}, 1000 \mathrm{~mL}$ deionized $\mathrm{H}_{2} \mathrm{O}$ ), CYS80 (sucrose $80.0 \mathrm{~g}$, yellow cornmeal $50.0 \mathrm{~g}$, yeast extract $1.0 \mathrm{~g}, 1000 \mathrm{~mL}$ deionized $\mathrm{H}_{2} \mathrm{O}$ ), MPP (maltose $25.0 \mathrm{~g}$, glucose $10.0 \mathrm{~g}$, dried baker's yeast $5.0 \mathrm{~g}$, Pharmamedia (Archer Daniels Midland, Decatur, IL, USA) 10.0 g, $1000 \mathrm{~mL}$ deionized $\mathrm{H}_{2} \mathrm{O}$ ), YES (150.0 g sucrose, $20.0 \mathrm{~g}$ yeast extract, $0.5 \mathrm{~g} \mathrm{MgSO}_{4} .7 \mathrm{H}_{2} \mathrm{O}, 0.010 \mathrm{~g} \mathrm{ZnSO}_{4} .7 \mathrm{H}_{2} \mathrm{O}, 0.005 \mathrm{~g} \mathrm{CuSO}_{4} .5 \mathrm{H}_{2} \mathrm{O}, 1000 \mathrm{~mL} \mathrm{H}_{2} \mathrm{O}$ ) and MGP (glycerol $50.0 \mathrm{~g}$, molasses $10.0 \mathrm{~g}$, Pharmamedia, $5.0 \mathrm{~g}$, sodium glutamate $5.0 \mathrm{~g}$, NaCl $1.0 \mathrm{~g}$, $\mathrm{KH}_{2} \mathrm{PO}_{4} 1.0 \mathrm{~g}, \mathrm{MgSO}_{4} .7 \mathrm{H}_{2} \mathrm{O}$ $0.5 \mathrm{~g}, \mathrm{ZnSO}_{4} .7 \mathrm{H}_{2} \mathrm{O} 0.05 \mathrm{~g}, 1000 \mathrm{~mL}$ deionized $\mathrm{H}_{2} \mathrm{O}$ ). For strain DPL-12808, the media set used Wheat 1 , CYS80, MMK2 (mannitol 40.0 g, yeast extract 5.0 g, Murashige \& Skoog Salts (M-5524, Sigma Aldrich, St. Louis, MO, USA) $4.3 \mathrm{~g}$, $1000 \mathrm{~mL}$ deionized $\mathrm{H}_{2} \mathrm{O}$ ), Supermalt (malt extract $50.0 \mathrm{~g}$, yeast extract $10.0 \mathrm{~g}, \mathrm{FeSO}_{4} .7 \mathrm{H}_{2} \mathrm{O} 0.02 \mathrm{~g}$, $\mathrm{ZnSO}_{4} .7 \mathrm{H}_{2} \mathrm{O} 0.007 \mathrm{~g}, 1000 \mathrm{~mL}$ deionized $\mathrm{H}_{2} \mathrm{O}$ ) and $\mathrm{MOF}$ (mannitol $75.0 \mathrm{~g}$, oat flour $15.0 \mathrm{~g}$, yeast extract $5.0 \mathrm{~g}$, L-glutamic acid $4.0 \mathrm{~g}$, MES (2-(N-morpholino)ethanesulfonic acid) $16.2 \mathrm{~g}, 1000 \mathrm{~mL}$ deionized $\mathrm{H}_{2} \mathrm{O}$ ). For strain TTI-1079, the media set used included Wheat 1, CLA (5.0 g yeast autolysate, $40.0 \mathrm{~g}$ corn meal, 40.0 lactose, $1000 \mathrm{~mL}$ deionized $\left.\mathrm{H}_{2} \mathrm{O}\right)$, MMK2, YES and GLX (10.0 g peptone, $21.0 \mathrm{~g}$ malt extract, $40.0 \mathrm{~g}$ glycerol, $1.0 \mathrm{~g}$ carboxymethyl cellulose, $1000 \mathrm{~mL}$ deionized $\mathrm{H}_{2} \mathrm{O}$ ). Cultures in Wheat 1, CYS80 and CLA media were incubated statically with vials slanted at a $45^{\circ}$ angle; the other media were agitated at $220 \mathrm{rpm}$. Fermentations were grown at $24{ }^{\circ} \mathrm{C}$ for 14 days, after which $17 \mathrm{~mL}$ of 2-butanone was added and agitated at $220 \mathrm{rpm}$ for $2 \mathrm{~h}$. Eight $\mathrm{mL}$ of the organic phase were transferred to a clean glass vial and evaporated to dryness. The dried extracts were dissolved in $0.5 \mathrm{~mL}$ of DMSO prior to assay.

\subsection{Zone of Inhibition Assays}

Overnight cultures of $S$. aureus ATCC 43300 grown in Luria-Bertani medium (LB), Sigma Aldrich), and C. albicans ATCC 10231 and C. neoformans H99 grown in YM broth (malt extract 10 g, yeast extract $2 \mathrm{~g}$ in deionized $1000 \mathrm{~mL} \mathrm{H} \mathrm{H}_{2} \mathrm{O}$ ) at $37^{\circ} \mathrm{C}$ were diluted with sterile $\mathrm{H}_{2} \mathrm{O}$ to an $\mathrm{OD}_{600}$ of 0.4 for $S$. aureus and 0.8 for $C$. albicans and $C$. neoformans. One-milliliter aliquots of the resulting cell suspensions were mixed with $35 \mathrm{~mL}$ aliquots of YMA (LB agar for $S$. aureus) at $45{ }^{\circ} \mathrm{C}$ and dispensed into one-well Omnitray (Thermofisher Nunc, Grand Island, NY, USA) plates. A 35-well pattern of test wells (4 mm diam) was formed in the solidified agar by aspiration of wells with a Luer-lock syringe or by molding wells with a custom 3D-printed pin lid (V \& P Scientific, San Diego, CA, USA), and $10 \mu \mathrm{L}$ of each extract in DMSO was applied to each well. C. albicans was incubated at $25^{\circ} \mathrm{C}$, S. aureus at $37^{\circ} \mathrm{C}$ and $C$. neoformans was incubated at both temperatures. Zones of inhibition were photographed after $72 \mathrm{~h}$. During screening, amphotericin B was the positive control or antifungal assays and a mixture of chlortetracycline and streptomycin were the positive controls for antibacterial assays. 


\subsection{Isolation and Characterization of Active Compounds from Strain TTI-0467}

Strain TTI-0467 was selected for scale up and isolation of the active compounds. Bioassay-guided fractionation was used to identify active compounds in the crude extract of TTI-0467. The strain was grown in1-L bottles containing YES liquid media infused into vermiculite as a solid matrix to promote surface growth and mycelial differentiation [20]. To prepare the media, $340 \mathrm{~mL}$ of coarse vermiculite were added to each of eight 1-L glass bottles and autoclaved. When bottles were cooled, $120 \mathrm{~mL}$ of liquid YES media were added to each bottle along with $2 \mathrm{~mL}$ of a four-day-old TTI-0467 seed culture grown on SMYA liquid medium. Bottles were rotated on a cell production roller apparatus (Bellco, Vineland, NJ, USA,) until the mycelium formed a solid mass in the vermiculite matrix after 3 days, then bottles continued incubating without rolling. After 14 days, $350 \mathrm{~mL}$ of 2-butanone was added to each 1-L bottle and agitated for $4 \mathrm{~h}$ at $220 \mathrm{rpm}$. The extracted material was coarsely filtered to remove mycelium and vermiculite, and then filtered a second time to remove additional mycelia. The organic phase was separated and dried under vacuum, yielding $1.89 \mathrm{~g}$ of crude extract. The extract was adsorbed onto Celite (diatomaceous earth) and loaded into a vacuum liquid chromatography column (silica gel 60, $10 \times 7 \mathrm{~cm}$ ). Fractions were eluted successively with hexane, ethyl acetate (EtOAc):methanol $(\mathrm{MeOH})(1: 1 v / v)$, and $\mathrm{MeOH}$. The MeOH fraction was dried, applied to a LH-20 column (30 $\times 3 \mathrm{~cm}$, Sephadex, GE Healthcare, Uppsala, Sweden) and eluted with $\mathrm{MeOH}: \mathrm{CH}_{2} \mathrm{Cl}_{2}(1: 1)$. Fractions 6-15 containing the bioactive compounds were pooled and dried. The resulting mixture was purified using semi-preparative HPLC (Zorbax SB-C 18 column, Agilent Technologies, Santa Clara, CA, USA); $5 \mu \mathrm{m} ; 9.4 \times 250 \mathrm{~mm}, 40{ }^{\circ} \mathrm{C}$; isocratic ternary mixture for $25 \mathrm{~min}$ (40.5:19.0:40.5 A:B:C; (A), $0.1 \%$ trifluoroacetic acid (TFA) in acetonitrile, (B), $0.1 \%$ TFA in $\mathrm{H}_{2} \mathrm{O}$; solvent $\mathrm{C}, \mathrm{MeOH}, 4.0 \mathrm{~mL} / \mathrm{min}$ ), yielding $70 \mathrm{mg}$ of $\mathbf{1}$ (sum of the two isomers) and $36 \mathrm{mg}$ of $\mathbf{2}$ (sum of the two isomers). Peak identity was confirmed by HPLC (Ace Equivalence $C_{18}$ column $150 \times 4.6 \mathrm{~mm}, 5-\mu \mathrm{m}, 30{ }^{\circ} \mathrm{C}$ ). Gradient elution, $60 \%$ A for $6 \mathrm{~min}$ then from $60-70 \% \mathrm{~A}$ in $12 \mathrm{~min}, 1.0 \mathrm{~mL} / \mathrm{min}$. The mobile phase consisted of (A) $0.1 \%$ formic acid in acetonitrile and (B) $0.1 \%$ aqueous formic acid.

NMR data were collected on a 500-MHz NMR instrument (Bruker, Billerica, MA, USA) equipped with a 5 -mm triple resonance cryoprobe at $298 \mathrm{~K}$, with DMSO- $d_{6}$ as solvent. Semipreparative separations and HPLC-MS analyses were performed on an Agilent HPLC 1260 system equipped with a diode array detector (DAD) and coupled to an Agilent 6120 single quadrupole mass spectrometer (MS). HRMS data were acquired on an Orbitrap Fusion ${ }^{\mathrm{TM}}$ Tribrid $^{\mathrm{TM}}$ mass spectrometer (Thermo Scientific $^{\mathrm{TM}}$, Grand Island, NY, USA) with direct infusion. The Orbitrap Fusion was operated with measurement of FTMS ${ }^{1}$ at a resolution of 120,000 FWHM, scan range of $m / z$ 150-1250, automated gain control (ACG) target 2e5, and maximum injection time of $100 \mathrm{~ms}$; the FTMS ${ }^{2}$ spectra were collected with optimum higher collisional dissociation (HCD) energy, scan range $\mathrm{m} / \mathrm{z}$ 150-2000, AGC target 5e4, $2 \mathrm{~m} / \mathrm{z}$ isolation window.

\subsection{Determination of Absolute Configuration of Amino Acids}

The determination of the absolute configuration of the amino acid units in $\mathbf{1}$ and $\mathbf{2}$ was accomplished using a modified version of Marfey's method [21]. The HPLC analysis used the same column used for analysis of fermentation extracts and was held at $30^{\circ} \mathrm{C}$. To achieve resolution between $\beta$-Ala and L-Ala, the same ternary solvent mixture used for semi-preparative separation was applied in a gradient from 10:80:10 to 20:60:20 A:B:C in $28 \mathrm{~min}$, and then to 50:0:50 during 12 more min, totaling $40 \mathrm{~min}$ of analysis, at $1.0 \mathrm{~mL} / \mathrm{min}$. Amino acid derivatives were detected by UV at $340 \mathrm{~nm}$ and by positive ion electrospray ionization mass spectrometry (ESI-MS).

\subsection{Minimum Inhibitory Concentration (MIC) Assays}

To quantify the inhibitory concentrations of the sphaerostilbellins for select strains of fungal and bacterial pathogens, MICs were measured using species-specific modifications to standard CLSI testing methods [22]. Overnight cultures of S. aureus ATCC 43300 in LB media, and C. albicans ATCC 10231 
and C. neoformans $\mathrm{H} 99$ in YM media were diluted with sterile $\mathrm{H}_{2} \mathrm{O}$ to an $\mathrm{OD}_{600}$ of 0.4 for S. aureus and 0.8 for C. albicans and C. neoformans. For Aspergillus fumigatus FGSC A1240, conidia from a sporulating agar culture were used. Each suspension of cells or conidia was diluted 1000× in RPMI-1640 buffered with MOPS (Sigma-Aldrich). Stock solutions of the active compounds were prepared in DMSO at $1.28 \mathrm{mM}$. The final cell suspension $(195 \mu \mathrm{L})$ was transferred to a 96-well plate containing $5 \mu \mathrm{L}$ of stock solution for each active compound, and subsequently serially diluted to achieve a dose range of 0.06-64 $\mu \mathrm{M}$. Growth was assessed at $24 \mathrm{~h}$ (S. aureus and C. albicans) or $72 \mathrm{~h}$ (C. neoformans, A. fumigatus) by adding $10 \%$ alamarBlue (Bio-Rad, Hercules, CA, USA) and incubating in the dark at $37^{\circ} \mathrm{C}$ until color developed. Each compound was tested in duplicate. A streptomycin-chlortetracycline mixture was used as a positive control for S. aureus, and amphotericin B was used for C. albicans and C. neoformans.

\subsection{Macrophage-Fungal Co-Incubation and Macrophage Cytotoxicity Assays}

The macrophage-C. neoformans co-incubation assay was adapted from [23]. J774A.1 macrophagelike murine cells grown in DMEM (Dulbecco's Modified Eagle Medium, Sigma-Aldrich) were harvested, washed in PBS, transferred to 96-well tissue culture plates at $10^{5}$ cells/well, and incubated overnight at $37^{\circ} \mathrm{C}$ and $5 \% \mathrm{CO}_{2}$. The C. neoformans strain $\mathrm{H} 99$ was incubated in YPD medium (1\% yeast extract, $2 \%$ peptone, $2 \%$ dextrose) overnight with shaking at $37^{\circ} \mathrm{C}$, washed with $\mathrm{PBS}$, and resuspended in DMEM medium at $10^{3}$ cells/ml. Sphaerostilbellins ( $\mathbf{1}$ and $\mathbf{2}$ ) were prepared in serial 2-fold dilutions in DMEM and DMEM containing $\mathrm{H} 99$ cells to achieve a dose range of $0.03-32 \mu \mathrm{M}$. The macrophage medium was replaced with the DMEM medium containing compound or fungal cells plus compound and incubated for 24 to $48 \mathrm{~h}$ at $37^{\circ} \mathrm{C}$ and $5 \% \mathrm{CO}_{2}$. Macrophage viability was assessed by the addition of $10 \%$ alamarBlue and incubating for $3 \mathrm{~h}$ at $37{ }^{\circ} \mathrm{C}$ and $5 \% \mathrm{CO}_{2}$ prior to fluorescence measurement (FLUORStar Optima plate reader, BMG Labtech, Cary, NC, USA). Fungal growth was assessed visually at $48 \mathrm{~h}$. To test for fungal survival, samples from each well were plated onto YPD agar and incubated at $30{ }^{\circ} \mathrm{C}$. Each compound was tested in duplicate biological replicates.

\section{Results and Discussion}

During screening of extracts from fungal fermentations for antifungal activity using agar zone of inhibition assays, extracts of S. toxica, TTI-0467, DPL-12808, and TTI-1079, exhibited large, clear inhibition zones against Staphylococcus aureus, Candida albicans and C. neoformans [8] on most of the media tested (Figures S1-S3).

The bioactive components were tracked by bioactivity-guided HPLC fractionation of the crude extract of strain TTI-0467 grown in a solid wheat medium. HPLC analysis indicated the presence of at least two active compounds. Chromatographic separations afforded an enriched fraction containing four peaks, from which peaks 1 (minor) and 3 (major) showed $m / z=1701$ and peaks 2 (minor) and 4 (major) had $m / z=1786$. The high molecular weight and the absence of UV-visible absorption suggested a peptidic nature for the molecules. Upon separation of all four peaks and subsequent HPLC analysis, it was observed that upon reinjection of individual peaks, both pairs of peaks with the same nominal mass interconverted between two forms, with the predominance of peaks 3 and 4 (Figure S4). While NMR analysis of purified compounds in $\mathrm{CD}_{3} \mathrm{OD}$ showed a complex superposition of two different sets of signals (Figure S5), spectra obtained for molecules in DMSO-d6 coalesced to a single set of sharp signals. Therefore, for structure elucidation, peaks 2 and 4, representing the major compound, were considered as compound 1, while peaks 1 and 3 were defined as compound 2.

Initial HRMS analysis determined the molecular formula of $\mathbf{1}$ as $\mathrm{C}_{86} \mathrm{H}_{152} \mathrm{~N}_{20} \mathrm{O}_{20}(\mathrm{~m} / z$ 893.5828, $\left.[\mathrm{M}+2 \mathrm{H}]^{2+}, \Delta=0.40 \mathrm{ppm}\right)$, and for compound 2 as $\mathrm{C}_{82} \mathrm{H}_{145} \mathrm{~N}_{19} \mathrm{O}_{19}\left(\mathrm{~m} / \mathrm{z} 851.0560,[\mathrm{M}+2 \mathrm{H}]^{2+}\right.$, $\Delta=-0.03 \mathrm{ppm})$. The $85.0528 \mathrm{Da}$ difference between the two molecules corresponded to a $\mathrm{C}_{4} \mathrm{H}_{7} \mathrm{NO}$ residue indicating that 2 had one less aminoisobutyric acid (Aib) residue. Comparison of HRMS data with peptide databases [17,24,25] identified two lipopeptaibiotics, SCH 466,457 and SCH 466,456 from an unidentified fungus characterized at Schering Plough [26] that had the same molecular weights as $\mathbf{1}$ and $\mathbf{2}$, respectively. However, ${ }^{1} \mathrm{H}$ - and ${ }^{13} \mathrm{C}-\mathrm{NMR}$ analysis for $\mathbf{1}$ and $\mathbf{2}$ (Table 1 ), revealed structural 
differences between the isolated compounds and the $\mathrm{SCH}$ peptaibols. The most notable differences were the absence of a ${ }^{13} \mathrm{C}$-NMR peak at $\delta 158$, indicating the lack of an arginine residue, and the presence of several correlated multiplets at $\delta 2.2-2.4$ and $\delta 3.0-3.3$ in the ${ }^{1} \mathrm{H}-\mathrm{NMR}$ spectra, indicating the presence of $\beta$-amino acids, whereas in the $\mathrm{SCH}$ peptaibols only a glycine peak was observed in this region at $\delta 3.05$. Moreover, the earlier report made no mention of an interconversion between two forms. These differences led us to undertake a thorough characterization of the chemical structures of 1 and 2.

Table 1. ${ }^{1} \mathrm{H}$ - and ${ }^{13} \mathrm{C}-\mathrm{NMR}$ data for compound 1 in DMSO (500 and $125 \mathrm{MHz}$ for ${ }^{1} \mathrm{H}-$ and ${ }^{13} \mathrm{C}-$, respectively).

\begin{tabular}{|c|c|c|c|c|c|c|c|}
\hline Residue. & Position & $\delta \mathrm{C}$ & $\begin{array}{l}\delta \mathrm{H}, \text { mult } \\
(\mathrm{J} \text { in } \mathrm{Hz})\end{array}$ & Residue & Position & $\delta \mathrm{C}$ & $\begin{array}{l}\delta \mathrm{H}, \text { mult } \\
(\mathrm{J} \text { in } \mathrm{Hz})\end{array}$ \\
\hline \multirow[t]{15}{*}{ MOTDA } & 1 & 169.40 & & $\mathrm{Aib}_{9}$ & $\mathrm{NH}$ & & $8.02, \mathrm{~s}$ \\
\hline & 2 & 50.83 & $3.80, \mathrm{q}(6.9)$ & & $\alpha$ & 55.85 & \\
\hline & $2^{\prime}$ & 12.45 & $1.15, \mathrm{~d}(6.9)$ & & $\beta-1$ & 23.13 & $1.39, \mathrm{~m}^{\mathrm{a}}$ \\
\hline & 3 & 206.39 & & & $\beta-2$ & 24.30 & $1.33, \mathrm{~m}^{\mathrm{a}}$ \\
\hline & 4 & 40.42 & $2.47, \mathrm{~m}$ & & $\mathrm{C}=\mathrm{O}$ & 174.08 & \\
\hline & 5 & 22.84 & $1.40, \mathrm{~m}$ & $\beta-\mathrm{Ala}_{10}$ & $\mathrm{NH}$ & & $7.44, \mathrm{t}(5.5)$ \\
\hline & 6 & 22.04 & $1.22, \mathrm{~m}$ & & $\alpha$ & 35.81 & $\begin{array}{l}\text { a: } 3.32, \mathrm{~m} ; \\
\text { b: } 3.14, \mathrm{~m}\end{array}$ \\
\hline & 7 & 28.69 & $1.16, \mathrm{~m}$ & & $\beta$ & 35.09 & $2.29, \mathrm{~m}$ \\
\hline & 8 & 28.89 & $1.20, \mathrm{~m}$ & & $\mathrm{C}=\mathrm{O}$ & 171.18 & \\
\hline & 9 & 28.95 & $1.21, \mathrm{~m}$ & L-Ala 11 & $\mathrm{NH}$ & & $8.12, \mathrm{~d}(4.8)$ \\
\hline & 10 & 28.82 & $1.24, \mathrm{~m}$ & & $\alpha$ & 49.19 & $4.10, \mathrm{q}(6.6)$ \\
\hline & 11 & 28.99 & $1.25, \mathrm{~m}$ & & $\beta$ & 17.09 & $1.18, \mathrm{~m}$ \\
\hline & 12 & 28.64 & $1.36, \mathrm{~m}$ & & $\mathrm{C}=\mathrm{O}$ & 172.20 & \\
\hline & 13 & 31.23 & $1.23, \mathrm{~m}$ & $\mathrm{Aib}_{12}$ & $\mathrm{NH}$ & & $8.04, \mathrm{~s}$ \\
\hline & 14 & 13.91 & $0.85, \mathrm{~m}$ & & $\alpha$ & 56.06 & \\
\hline \multirow[t]{5}{*}{$\mathrm{L}_{-P r o}$} & $\alpha$ & 60.13 & $\begin{array}{c}4.26 \\
\text { dd }(5.8,7.8)\end{array}$ & & $\beta-1$ & 23.38 & $1.27, \mathrm{~m}^{\mathrm{a}}$ \\
\hline & $\beta$ & 28.45 & $\begin{array}{l}\text { a: } 2.16, \mathrm{~m} ; \\
\text { b: } 1.93, \mathrm{~m}\end{array}$ & & $\beta-2$ & 25.75 & $1.37, \mathrm{~m}^{\mathrm{a}}$ \\
\hline & $\gamma$ & 24.57 & $\begin{array}{l}\text { a: } 2.02, \mathrm{~m} ; \\
\text { b: } 1.92, \mathrm{~m}\end{array}$ & & $\mathrm{C}=\mathrm{O}$ & 174.09 & \\
\hline & $\delta$ & 47.57 & $3.64, \mathrm{t}(6.6)$ & $\beta-\mathrm{Ala}_{13}$ & $\mathrm{NH}$ & & $7.50, \mathrm{t}(5.6)$ \\
\hline & $\mathrm{C}=\mathrm{O}$ & 172.43 & & & $\alpha$ & 35.83 & $\begin{array}{l}\text { a: } 3.30, \mathrm{~m} ; \\
\text { b: } 3.21, \mathrm{~m}\end{array}$ \\
\hline \multirow[t]{5}{*}{$\mathrm{Aib}_{2}$} & $\mathrm{NH}$ & & $8.55, \mathrm{~s}$ & & $\beta$ & 35.06 & $2.31, \mathrm{~m}$ \\
\hline & $\alpha$ & 55.96 & & & $\mathrm{C}=\mathrm{O}$ & 171.54 & \\
\hline & $\beta 1$ & 23.90 & $1.34, \mathrm{~m}^{\mathrm{a}}$ & L-Ala 14 & $\mathrm{NH}$ & & $8.19, \mathrm{~d}(4.7)$ \\
\hline & $\beta 2$ & 25.50 & $1.32, \mathrm{~m}^{\mathrm{a}}$ & & $\alpha$ & 49.94 & $4.03, \mathrm{~m}^{\mathrm{d}}$ \\
\hline & $\mathrm{C}=\mathrm{O}$ & 175.38 & & & $\beta$ & 16.63 & $1.24, \mathrm{~m}$ \\
\hline \multirow[t]{5}{*}{$\mathrm{Aib}_{3}$} & $\mathrm{NH}$ & & $7.95, \mathrm{~s}$ & & $\mathrm{C}=\mathrm{O}$ & 174.01 & \\
\hline & $\alpha$ & 55.84 & & $\mathrm{Aib}_{15}$ & $\mathrm{NH}$ & & $8.40, \mathrm{~s}$ \\
\hline & $\beta-1$ & 24.58 & $1.39, \mathrm{~m}^{\mathrm{a}}$ & & $\alpha$ & 55.99 & \\
\hline & $\beta-2$ & 25.74 & $1.36, \mathrm{~m}^{\mathrm{a}}$ & & $\beta-1$ & 24.10 & $1.37, \mathrm{~m}^{\mathrm{a}}$ \\
\hline & $\mathrm{C}=\mathrm{O}$ & 175.19 & & & $\beta-2$ & 24.96 & $1.36, \mathrm{~m}^{\mathrm{a}}$ \\
\hline
\end{tabular}


Table 1. Cont.

\begin{tabular}{|c|c|c|c|c|c|c|c|}
\hline Residue. & Position & $\delta \mathrm{C}$ & $\begin{array}{l}\delta \mathrm{H}, \text { mult } \\
(\mathrm{J} \text { in } \mathrm{Hz})\end{array}$ & Residue & Position & $\delta \mathrm{C}$ & $\begin{array}{l}\delta \mathrm{H}, \text { mult } \\
(\mathrm{J} \text { in } \mathrm{Hz})\end{array}$ \\
\hline \multirow[t]{5}{*}{$\mathrm{Aib}_{4}$} & $\mathrm{NH}$ & & $7.70, \mathrm{~s}^{\mathrm{b}}$ & & $\mathrm{C}=\mathrm{O}$ & 175.34 & \\
\hline & $\alpha$ & 55.88 & & $\mathrm{Aib}_{16}$ & $\mathrm{NH}$ & & $7.80, \mathrm{~s}$ \\
\hline & $\beta-1$ & 24.92 & $1.34, \mathrm{~m}^{\mathrm{a}}$ & & $\alpha$ & 55.69 & \\
\hline & $\beta-2$ & 26.46 & $1.30, \mathrm{~m}^{\mathrm{a}}$ & & $\beta-1$ & 22.93 & $1.29, \mathrm{~m}^{\mathrm{a}}$ \\
\hline & $\mathrm{C}=\mathrm{O}$ & 175.14 & & & $\beta-2$ & 25.80 & $1.32, \mathrm{~m}^{\mathrm{a}}$ \\
\hline \multirow[t]{4}{*}{$\mathrm{L}^{-\mathrm{Ala}_{5}}$} & $\mathrm{NH}$ & & $7.71, \mathrm{~d}^{\mathrm{b}}$ & & $\mathrm{C}=\mathrm{O}$ & 175.26 & \\
\hline & $\alpha$ & 50.02 & $3.93, \mathrm{~m}^{\mathrm{c}}$ & $\mathrm{Aib}_{17}$ & $\mathrm{NH}$ & & $7.67, \mathrm{~s}$ \\
\hline & $\beta$ & 16.47 & $1.28, \mathrm{~m}$ & & $\alpha$ & 55.95 & \\
\hline & $\mathrm{C}=\mathrm{O}$ & 172.00 & & & $\beta-1$ & 21.99 & $1.33, \mathrm{~m}^{\mathrm{a}}$ \\
\hline \multirow[t]{5}{*}{$\mathrm{Aib}_{6}$} & $\mathrm{NH}$ & & $7.34, \mathrm{~s}$ & & $\beta-2$ & 26.64 & $1.35, \mathrm{~m}^{\mathrm{a}}$ \\
\hline & $\alpha$ & 56.01 & & & $\mathrm{C}=\mathrm{O}$ & 173.37 & \\
\hline & $\beta-1$ & 24.67 & $1.36, \mathrm{~m}^{\mathrm{a}}$ & $\mathrm{L}_{-} \mathrm{Ala}_{18}$ & $\mathrm{NH}$ & & $7.56, \mathrm{~d}(7.8)$ \\
\hline & $\beta-2$ & 24.70 & $1.36, \mathrm{~m}^{\mathrm{a}}$ & & $\alpha$ & 48.96 & $4.04, \mathrm{~m}^{\mathrm{d}}$ \\
\hline & $\mathrm{C}=\mathrm{O}$ & 174.02 & & & $\beta$ & 17.11 & $1.31, \mathrm{~m}$ \\
\hline \multirow[t]{4}{*}{$\beta-\mathrm{Ala}_{7}$} & $\mathrm{NH}$ & & $7.13, \mathrm{t}(5.4)$ & & $\mathrm{C}=\mathrm{O}$ & 172.05 & \\
\hline & $\alpha$ & 35.60 & $\begin{array}{l}\text { a: } 3.28, \mathrm{~m} ; \\
\mathrm{b}: 3.18, \mathrm{~m}\end{array}$ & Put & $\mathrm{NH}$ & & $7.39, \mathrm{t}(5.6)$ \\
\hline & $\beta$ & 35.20 & $2.35, \mathrm{~m}$ & & $\alpha$ & 37.90 & $\begin{array}{l}\text { a: } 3.10, \mathrm{~m} ; \\
\text { b: } 3.02, \mathrm{~m}\end{array}$ \\
\hline & $\mathrm{C}=\mathrm{O}$ & 171.04 & & & $\beta$ & 25.88 & $1.50, \mathrm{~m}^{\mathrm{e}}$ \\
\hline \multirow[t]{6}{*}{$\mathrm{L}-\mathrm{Val}_{8}$} & $\mathrm{NH}$ & & $8.00, \mathrm{~d}(7.0)$ & & $\gamma$ & 24.26 & $1.53, \mathrm{~m}^{\mathrm{e}}$ \\
\hline & $\alpha$ & 58.93 & $3.92, \mathrm{~m}^{\mathrm{c}}$ & & $\delta$ & 38.53 & $2.78, \mathrm{~m}$ \\
\hline & $\beta$ & 29.58 & $1.93, \mathrm{~m}$ & & $\mathrm{NH} 2$ & & $7.69, \mathrm{~m}^{\mathrm{b}}$ \\
\hline & $\gamma-1$ & 19.08 & $0.86, \mathrm{~m}$ & & & & \\
\hline & $\gamma-2$ & 18.68 & $0.87, \mathrm{~m}$ & & & & \\
\hline & $\mathrm{C}=\mathrm{O}$ & 170.78 & & & & & \\
\hline
\end{tabular}

For the major compound, $1{ }^{1} \mathrm{H}-,{ }^{13} \mathrm{C}-$, and 2D NMR experiments (COSY, HSQC, HMBC, ROESY) revealed the presence of nine 2-aminoisobutyric acid (Aib) residues, as well as four alanine (Ala) units, three $\beta$-alanine ( $\beta$-Ala) units, one valine (Val) unit, and one proline (Pro) unit (Table 1, Figures S6-S11). Linked to the proline residue at the $\mathrm{N}$-terminus was a 2-methyl-3-oxotetradecanoyl (MOTDA) residue (Figure 2). Observation of a ROESY correlation between the $\alpha$-methine hydrogen of the MOTDA residue with Pro2 $\delta \mathrm{H}$ indicated a s-trans configuration of the Pro residue (Table 1, Figure 2). Furthermore, COSY correlations also showed a spin system arising from an amide $\mathrm{NH}$ proton at $\delta 7.39$ connected to a 4-aminobutyl side-chain. The terminal H-4 methylene protons at $\delta 2.78$ showed a COSY correlation with an $\mathrm{NH}_{2}$ proton signal at $\delta 7.69$, characterized by a surprisingly strong deshielding effect, similar to observations in other peptaibiotics [27]. Extensive analysis of HMBC and ROESY data guided determination the amino acid sequence and the locations of the other units (Table 2, Figure 2). 


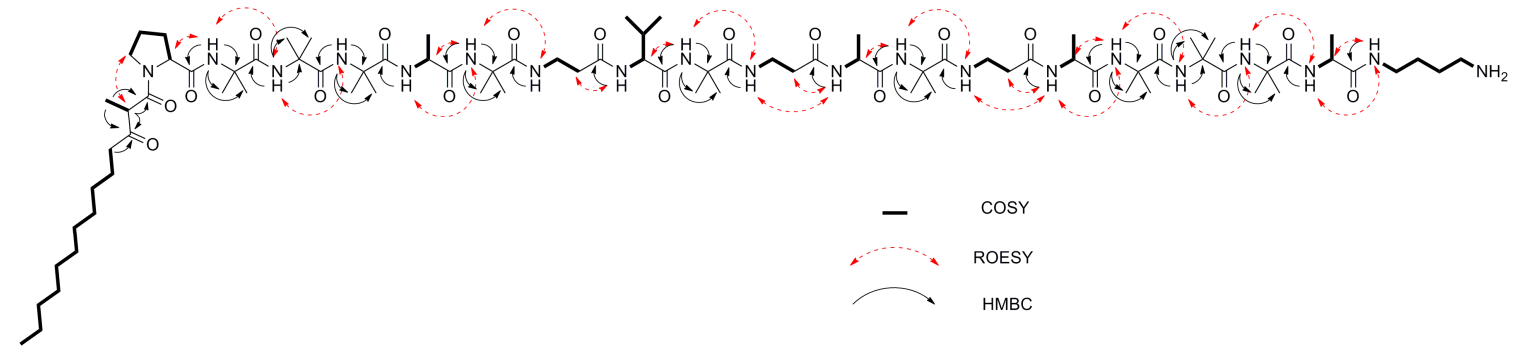

Figure 2. 2D NMR correlations used for structural characterization of compound 1.

Table 2. ${ }^{1} \mathrm{H}$ - and ${ }^{13} \mathrm{C}-\mathrm{NMR}$ data for compound 2 in DMSO- $d_{6}\left(500\right.$ and $125 \mathrm{MHz}$ for ${ }^{1} \mathrm{H}$ - and ${ }^{13} \mathrm{C}-$, respectively).

\begin{tabular}{|c|c|c|c|c|c|c|c|}
\hline Residue & Position & $\delta \mathrm{C}$ & $\begin{array}{l}\delta \mathrm{H}, \text { mult } \\
(\mathrm{J} \text { in } \mathrm{Hz})\end{array}$ & Residue & Position & $\delta \mathrm{C}$ & $\begin{array}{l}\delta \mathrm{H}, \text { mult } \\
(\mathrm{J} \text { in } \mathrm{Hz})\end{array}$ \\
\hline \multirow[t]{15}{*}{ MOTDA } & 1 & 169.40 & & $\mathrm{Aib}_{9}$ & $\mathrm{NH}$ & & $8.02, \mathrm{~s}$ \\
\hline & 2 & 50.83 & $3.80, q(6.9)$ & & $\alpha$ & 55.85 & \\
\hline & $2^{\prime}$ & 12.45 & $1.15, \mathrm{~d}(6.9)$ & & $\beta-1$ & 23.13 & $1.39, \mathrm{~m}^{\mathrm{a}}$ \\
\hline & 3 & 206.39 & & & $\beta-2$ & 24.30 & $1.33, \mathrm{~m}^{\mathrm{a}}$ \\
\hline & 4 & 40.42 & $2.47, \mathrm{~m}$ & & $\mathrm{C}=\mathrm{O}$ & 174.08 & \\
\hline & 5 & 22.84 & $1.40, \mathrm{~m}^{\mathrm{a}}$ & $\beta-\mathrm{Ala}_{10}$ & $\mathrm{NH}$ & & $7.44, \mathrm{~m}^{\mathrm{d}}$ \\
\hline & 6 & 22.04 & $1.24, \mathrm{~m}^{\mathrm{f}}$ & & $\alpha$ & 35.81 & $\begin{array}{l}\text { a: } 3.32, \mathrm{~m} ; \\
\mathrm{b}: 3.14, \mathrm{~m}\end{array}$ \\
\hline & 7 & 28.69 & $1.16, \mathrm{~m}^{\mathrm{f}}$ & & $\beta$ & 35.09 & $2.29, \mathrm{~m}$ \\
\hline & 8 & 28.89 & $1.20, \mathrm{~m}^{\mathrm{f}}$ & & $\mathrm{C}=\mathrm{O}$ & 171.18 & \\
\hline & 9 & 28.95 & $1.21, \mathrm{~m}^{\mathrm{f}}$ & L-Ala 11 & $\mathrm{NH}$ & & $8.10, \mathrm{~d}(4.8)$ \\
\hline & 10 & 28.82 & $1.24, \mathrm{~m}^{\mathrm{f}}$ & & $\alpha$ & 49.19 & $4.10, \mathrm{q}(6.6)$ \\
\hline & 11 & 28.99 & $1.25, \mathrm{~m}^{\mathrm{f}}$ & & $\beta$ & 17.15 & $1.18, \mathrm{~m}$ \\
\hline & 12 & 28.64 & $1.36, \mathrm{~m}^{\mathrm{a}}$ & & $\mathrm{C}=\mathrm{O}$ & 172.20 & \\
\hline & 13 & 31.23 & $1.23, \mathrm{~m}^{\mathrm{f}}$ & $\mathrm{Aib}_{12}$ & $\mathrm{NH}$ & & $8.04, \mathrm{~s}$ \\
\hline & 14 & 13.91 & $0.85, \mathrm{~m}$ & & $\alpha$ & 56.06 & \\
\hline \multirow[t]{5}{*}{$\mathrm{L}_{-P r o}$} & $\alpha$ & 60.13 & $\begin{array}{c}4.26, \\
\text { dd }(5.8,7.8)\end{array}$ & & $\beta-1$ & 23.38 & $1.27, \mathrm{~m}^{\mathrm{a}}$ \\
\hline & $\beta$ & 28.45 & $\begin{array}{l}\text { a: } 2.16, \mathrm{~m} ; \\
\text { b: } 1.93, \mathrm{~m}\end{array}$ & & $\beta-2$ & 25.75 & $1.37, \mathrm{~m}^{\mathrm{a}}$ \\
\hline & $\gamma$ & 24.57 & $\begin{array}{l}\text { a: } 2.02, \mathrm{~m} ; \\
\mathrm{b}: 1.92, \mathrm{~m}\end{array}$ & & $\mathrm{C}=\mathrm{O}$ & 174.03 & \\
\hline & $\delta$ & 47.57 & $3.64, \mathrm{t}(6.4) \mathrm{m}$ & $\beta-\mathrm{Ala}_{13}$ & $\mathrm{NH}$ & & $7.50, \mathrm{~m}^{\mathrm{e}}$ \\
\hline & $\mathrm{C}=\mathrm{O}$ & 172.43 & & & $\alpha$ & 35.83 & $\begin{array}{l}\text { a: } 3.30, \mathrm{~m} ; \\
\text { b: } 3.21, \mathrm{~m}\end{array}$ \\
\hline \multirow[t]{5}{*}{$\mathrm{Aib}_{2}$} & $\mathrm{NH}$ & & $8.55, \mathrm{~s}$ & & $\beta$ & 35.06 & $2.31, \mathrm{~m}$ \\
\hline & $\alpha$ & 55.96 & & & $\mathrm{C}=\mathrm{O}$ & 171.54 & \\
\hline & $\beta 1$ & 23.90 & $1.34, \mathrm{~m}^{\mathrm{a}}$ & L-Ala 14 & $\mathrm{NH}$ & & $8.14, \mathrm{~d}(4.7)$ \\
\hline & $\beta 2$ & 25.50 & $1.32, \mathrm{~m}^{\mathrm{a}}$ & & $\alpha$ & 49.70 & $4.03, \mathrm{~m}^{\mathrm{g}}$ \\
\hline & $\mathrm{C}=\mathrm{O}$ & 175.38 & & & $\beta$ & 16.74 & $1.24, \mathrm{~m}$ \\
\hline
\end{tabular}


Table 2. Cont.

\begin{tabular}{|c|c|c|c|c|c|c|c|}
\hline Residue & Position & $\delta \mathrm{C}$ & $\begin{array}{l}\delta \mathrm{H}, \text { mult } \\
(\mathrm{J} \text { in } \mathrm{Hz} \text { ) }\end{array}$ & Residue & Position & $\delta \mathrm{C}$ & $\begin{array}{l}\delta \mathrm{H}, \text { mult } \\
(\mathrm{J} \text { in } \mathrm{Hz})\end{array}$ \\
\hline \multirow[t]{5}{*}{$\mathrm{Aib}_{3}$} & $\mathrm{NH}$ & & $7.95, \mathrm{~s}$ & & $\mathrm{C}=\mathrm{O}$ & 173.97 & \\
\hline & $\alpha$ & 55.84 & & $\mathrm{Aib}_{15}$ & $\mathrm{NH}$ & & $8.41, \mathrm{~s}$ \\
\hline & $\beta-1$ & 24.58 & $1.39, \mathrm{~m}^{\mathrm{a}}$ & & $\alpha$ & 55.99 & \\
\hline & $\beta-2$ & 25.74 & $1.36, \mathrm{~m}^{\mathrm{a}}$ & & $\beta-1$ & 23.90 & $1.37, \mathrm{~m}^{\mathrm{a}}$ \\
\hline & $\mathrm{C}=\mathrm{O}$ & 175.19 & & & $\beta-2$ & 25.27 & $1.36, \mathrm{~m}^{\mathrm{a}}$ \\
\hline \multirow[t]{5}{*}{$\mathrm{Aib}_{4}$} & $\mathrm{NH}$ & & $7.70, \mathrm{~s}^{\mathrm{b}}$ & & $\mathrm{C}=\mathrm{O}$ & 175.00 & \\
\hline & $\alpha$ & 55.88 & & $\mathrm{Aib}_{16}$ & $\mathrm{NH}$ & & $7.71, \mathrm{~s}$ \\
\hline & $\beta-1$ & 24.92 & $1.34, \mathrm{~m}^{\mathrm{a}}$ & & $\alpha$ & 55.86 & \\
\hline & $\beta-2$ & 26.46 & $1.30, \mathrm{~m}^{\mathrm{a}}$ & & $\beta-1$ & 21.99 & $1.33, \mathrm{~m}^{\mathrm{a}}$ \\
\hline & $\mathrm{C}=\mathrm{O}$ & 175.14 & & & $\beta-2$ & 26.47 & $1.35, \mathrm{~m}^{\mathrm{a}}$ \\
\hline \multirow[t]{4}{*}{ L-Ala 5} & $\mathrm{NH}$ & & $7.71, \mathrm{~d}^{\mathrm{b}}$ & & $\mathrm{C}=\mathrm{O}$ & 173.49 & \\
\hline & $\alpha$ & 50.02 & $3.93, \mathrm{~m}^{\mathrm{c}}$ & L-Ala 17 & $\mathrm{NH}$ & & $7.49, \mathrm{~m}^{\mathrm{e}}$ \\
\hline & $\beta$ & 16.47 & $1.28, \mathrm{~m}$ & & $\alpha$ & 48.96 & $4.04, \mathrm{~m}^{\mathrm{g}}$ \\
\hline & $\mathrm{C}=\mathrm{O}$ & 172.00 & & & $\beta$ & 17.27 & $1.31, \mathrm{~m}$ \\
\hline \multirow[t]{5}{*}{$\mathrm{Aib}_{6}$} & $\mathrm{NH}$ & & $7.34, \mathrm{~s}$ & & $\mathrm{C}=\mathrm{O}$ & 172.05 & \\
\hline & $\alpha$ & 56.01 & & Put & $\mathrm{NH}$ & & $7.45, \mathrm{~m}^{\mathrm{d}}$ \\
\hline & $\beta-1$ & 24.67 & $1.36, \mathrm{~m}^{\mathrm{a}}$ & & $\alpha$ & 37.9 & $\begin{array}{l}\text { a: } 3.10, \mathrm{~m} ; \\
\text { b: } 3.02, \mathrm{~m}\end{array}$ \\
\hline & $\beta-2$ & 24.70 & $1.36, \mathrm{~m}^{\mathrm{a}}$ & & $\beta$ & 25.88 & $1.50, \mathrm{~m}^{\mathrm{h}}$ \\
\hline & $\mathrm{C}=\mathrm{O}$ & 174.02 & & & $\gamma$ & 24.26 & $1.53, \mathrm{~m}^{\mathrm{h}}$ \\
\hline \multirow[t]{4}{*}{$\beta-\mathrm{Ala}_{7}$} & $\mathrm{NH}$ & & $7.13, \mathrm{t}(5.4)$ & & $\delta$ & 38.49 & $2.78, \mathrm{~m}$ \\
\hline & $\alpha$ & 35.60 & $\begin{array}{c}\mathrm{a}: 3.28, \mathrm{~m} ; \mathrm{b}: \\
3.18, \mathrm{~m}\end{array}$ & & $\mathrm{NH} 2$ & & $7.69, \mathrm{~m}^{\mathrm{b}}$ \\
\hline & $\beta$ & 35.20 & $2.35, \mathrm{~m}$ & & & & \\
\hline & $\mathrm{C}=\mathrm{O}$ & 171.04 & & & & & \\
\hline \multirow[t]{6}{*}{$\mathrm{L}-\mathrm{Val}_{8}$} & $\mathrm{NH}$ & & $8.00, \mathrm{~d}(7.0)$ & & & & \\
\hline & $\alpha$ & 58.93 & $3.92, \mathrm{~m}^{\mathrm{c}}$ & & & & \\
\hline & $\beta$ & 29.58 & $1.93, \mathrm{~m}$ & & & & \\
\hline & $\gamma-1$ & 19.08 & $0.86, \mathrm{~m}$ & & & & \\
\hline & $\gamma-2$ & 18.68 & $0.87, \mathrm{~m}$ & & & & \\
\hline & $\mathrm{C}=\mathrm{O}$ & 170.78 & & & & & \\
\hline
\end{tabular}

The assigned sequence of amino acids was supported by HRMS/MS analysis (Figure 3). Fragmentation of the $[\mathrm{M}+2 \mathrm{H}]^{2+}$ ion at $m / z 893.5827$ resulted in a series of observable $\mathrm{b} / \mathrm{y}$ fragments, in accordance with the sequential loss of amino acid residues from the $\mathrm{N}$ - and $\mathrm{C}$ - termini, respectively. Interestingly, formation of specific pairs of $b / y$ fragments derived from the $\alpha$-cleavage of $\beta$-Ala ions were greatly suppressed or absent, a feature common in other peptaibiotics containing $\beta$-Ala residues $[28,29]$, which further supported the existence and positions of the $\beta$-Ala units in the proposed amino acid sequence. 

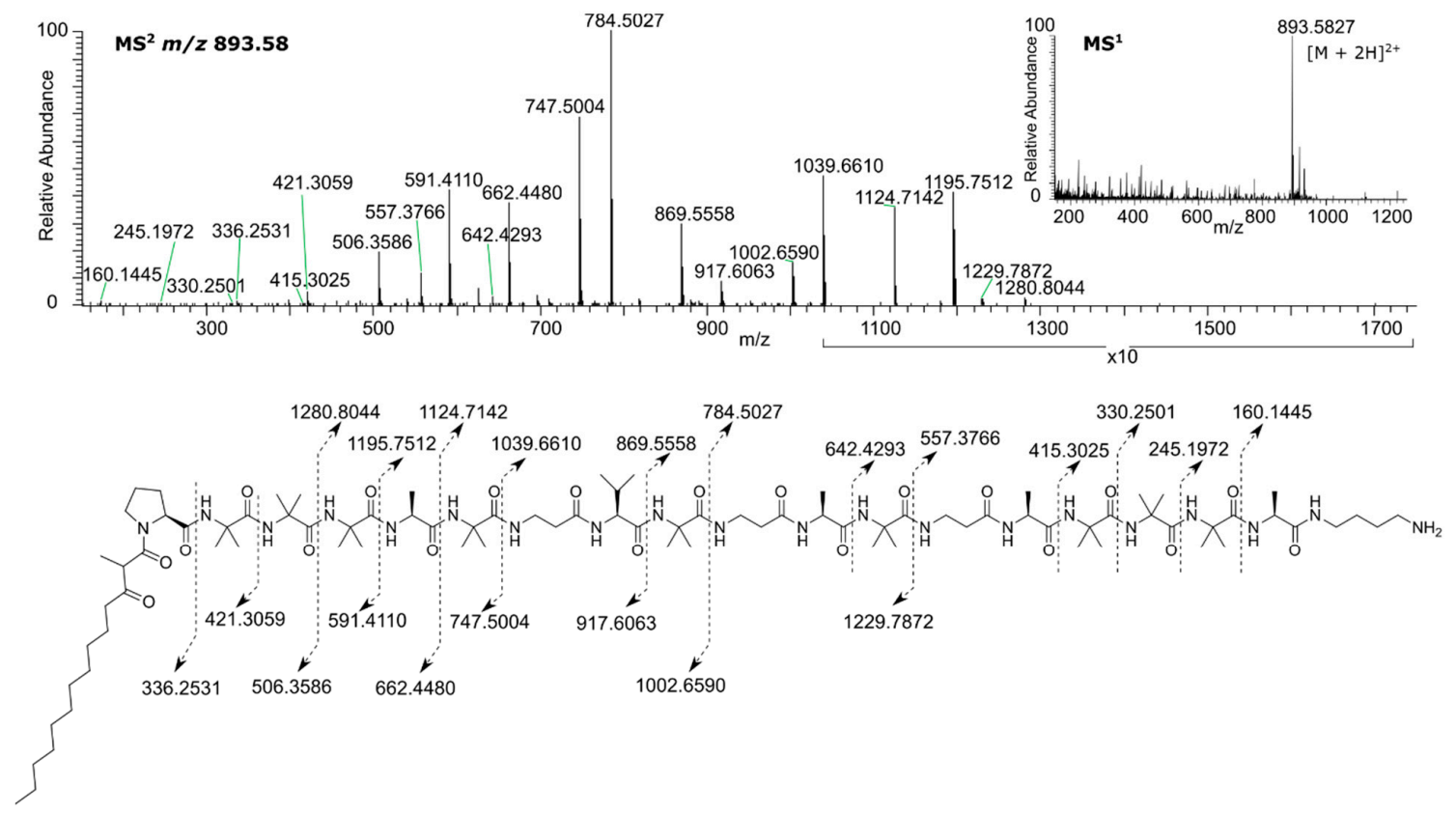

Figure 3. HRMS for sphaerostilbellin A (1).

$\mathrm{MS}^{2}$ analysis of the ion at $m / z 851.0560$ corresponding to the $[\mathrm{M}+2 \mathrm{H}]^{2+}$ ion for 2 showed an identical $b$ ion pattern and a $y$ ion series containing the incremental mass difference between $\mathbf{1}$ and $\mathbf{2}$, indicating the missing Aib among the last sequence of Aib residues (Figure 4). Analysis of ${ }^{1} \mathrm{H}$ NMR data showed the absence of an $\mathrm{NH}$ amide proton at $\delta 7.80$, attributed to residue $\mathrm{Aib}_{16}$ in $\mathbf{1}$. The absence of this peak, and the observation of a ROESY correlation between the amide NH proton of Aib 15 ( $\delta 8.41)$ with $\delta 7.70$, attributed to the $\mathrm{NH}$ amide proton of residue Aib 17 in $\mathbf{1}$ confirmed the absence of the residue Aib ${ }_{16}$ in 2. NMR data (Figure 5, Figures S12-S17) for 2 are provided in Table 2.
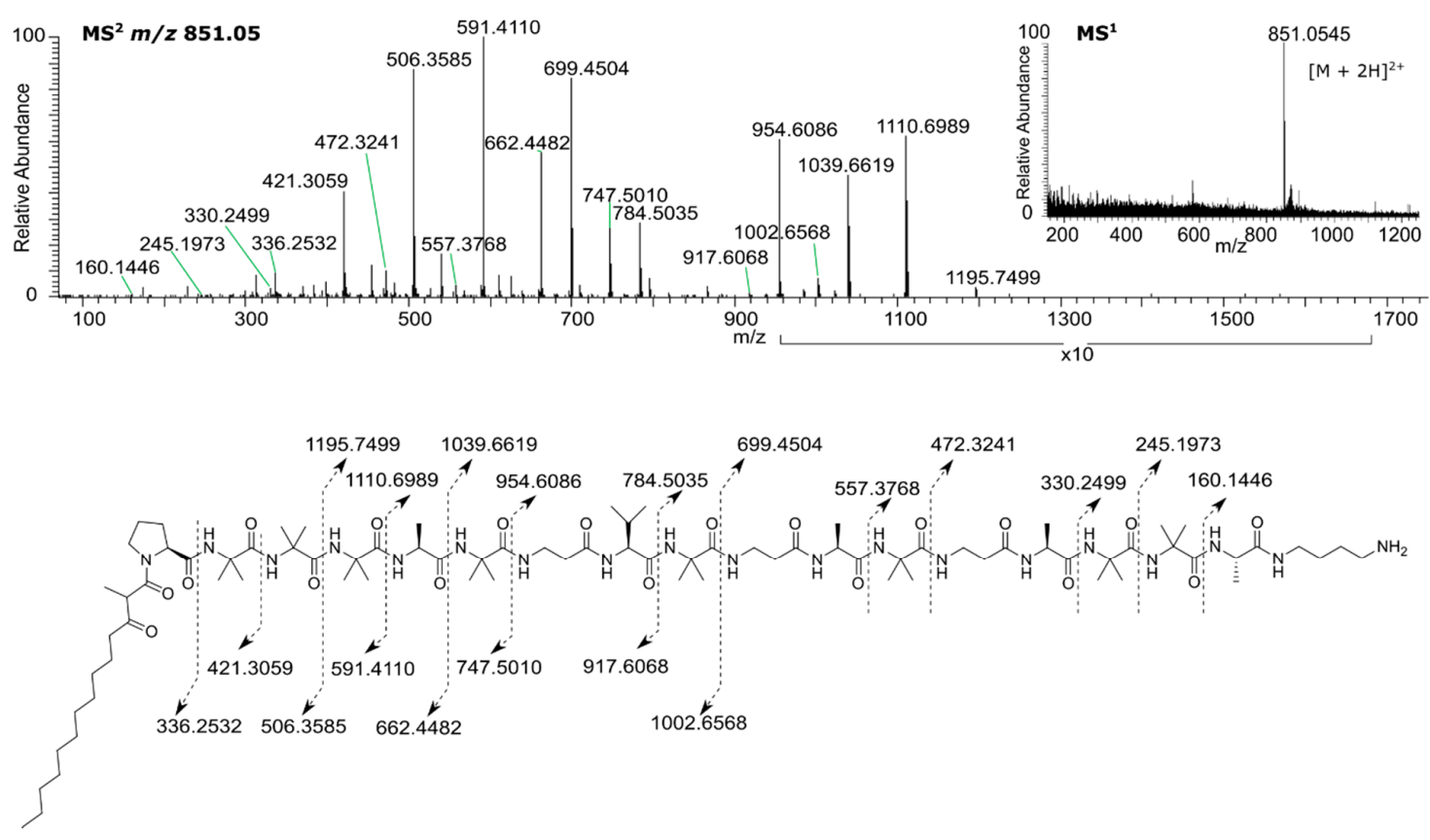

Figure 4. HRMS for sphaerostilbellin B (2). 


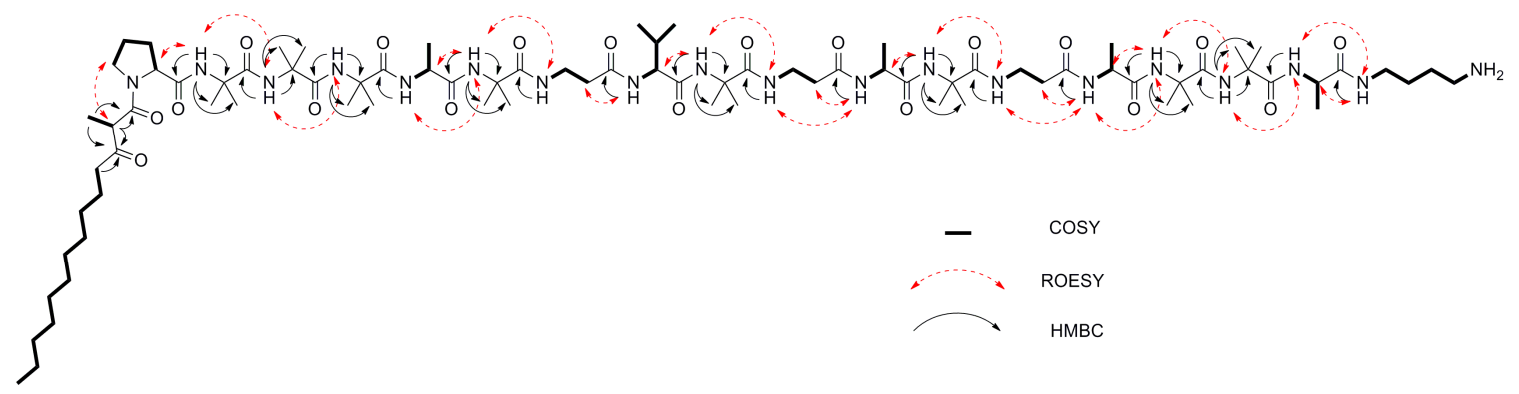

Figure 5. 2D NMR correlations used for structural characterization of compound 2.

Marfey's analysis of the amino acids present in the acid hydrolyzates of $\mathbf{1}$ and $\mathbf{2}$ confirmed the absolute configurations of the chiral amino acids as L-Ala, L-Pro, and L-Val (Figure S18). The LC-MS analysis of the Marfey's derivative standard amino acid mixture also confirmed the presence of $\beta$-Ala, Aib, and putrescine. L-Arg and Gly, present in the $\mathrm{SCH}$ peptaibols, were included among the derivatized standards for comparison but were absent from the samples, further confirming the differences among these compounds. It should be noted that relatively low absorbance for Aib and putrescine derivatives evident in chromatograms (Figure S18) are likely due to slower derivatization reaction rates required for complete reaction with Marfey's reagent [30,31].

The sphaerostilbellins exhibit several distinctive features. The presence of a primary amine unit at the C-terminal end is rare and only found in a few examples of peptaibiotics such as cicadapeptins [27] and MS-681a-d, isolated from a Myrothecium species [32]. To the best of our knowledge, this is the first report of a putrescine residue in a fungus-derived peptaibiotic. Substitution at the N-terminus with the polyketide-derived MOTDA unit has been reported in only a few other peptaibiotics such as lipohexin [33,34], SCH 466,456 and SCH466457 [26], SCH 643,432 and its unidentified isomer [35], and texenomycins A and B [36]. In the latter two examples, the pair of isolated peptaibiotics were characterized as isomers, and in the texenomycins, they differed in the stereochemistry of the methyl group arranged between the two carbonyl groups of the MOTDA residue.

In order to investigate whether the isomerization of sphaerostilbellins in LC-MS chromatograms was due to methyl group isomerization through a keto-enol equilibrium at the $\beta$-keto amide methine, a sample of purified sphaerostilbellin $\mathrm{A}$ was dissolved in $\mathrm{CD}_{3} \mathrm{OD}$ and left at room temperature for an extended period of time. Even after 110 days exposed to the protic solvent, there was no noticeable change in the ${ }^{1} \mathrm{H}-\mathrm{NMR}$ signal attributed to the methine hydrogen (Figure S19), indicating no appreciable deuterium exchange at the methine hydrogen and thus no racemization at this position under these conditions. Another possible explanation for the presence of two forms in $\mathrm{CD}_{3} \mathrm{OD}$ solution could arise from cis-trans proline conformational isomerization, a slow-exchange phenomenon that is widely recognized and observed in peptides, especially when proline is located as the penultimate residue [37-39]. ROESY analysis of 1 in $\mathrm{CD}_{3} \mathrm{OD}$ was consistent with the major conformer adopting a $s$-trans conformation, similar to what was observed in DMSO- $d 6$, however, these data did not provide positive evidence to unambiguously identify the minor form as the s-cis conformer.

Minimum inhibitory concentration (MIC) assays in liquid media for compounds $\mathbf{1}$ and $\mathbf{2}$ indicated strong potency towards all tested pathogens; S. aureus, A. fumigatus, C. albicans, and C. neoformans, with A. fumigatus exhibiting the highest sensitivity (Table 3). Antifungal activity was observed at lower concentrations than for inhibition of S. aureus for both compounds. Compound 1 showed a consistent two to four times lower MIC when compared to compound 2. Compounds $\mathbf{1}$ and $\mathbf{2}$ were also tested for toxicity against the murine macrophage-like cell line J774A.1 This cell line has been used extensively to assess in vitro phagocytic and antifungal activity against $C$. neoformans and other fungal pathogens [23,40]. Each compound displayed much higher inhibition/toxicity against these mammalian cells compared to fungal and bacterial cells, potentially arguing against their acting as non-specific cell toxins (Table 3). Additionally, the antifungal MIC for C. neoformans was identical whether the compounds were assayed with fungal cells alone or in a macrophage-fungal co-culture. 
Table 3. Minimum inhibitory concentration (MIC) values of peptaibiotics 1 and 2 against selected pathogens and murine macrophage cell line J774A.1.

\begin{tabular}{ccc}
\hline \multirow{2}{*}{ Pathogen or Cell Line } & \multicolumn{2}{c}{ Compound $(\mu \mathrm{M})$} \\
\cline { 2 - 3 } & Sphaerostilbellin A (1) & Sphaerostilbellin B (2) \\
\hline C. neoformans H99 $37^{\circ} \mathrm{C}$ & 2 & 2 \\
C. neoformans H99 $30^{\circ} \mathrm{C}$ & 2 & 2 \\
C. albicans ATCC 10231 & 4 & 2 \\
A. fumigatus FGSC A1240 & 1 & 1 \\
S. aureus ATCC 43300 & 8 & 32 \\
Murine macrophage J774A.1 & $>32$ & 32 \\
\hline
\end{tabular}

\section{Conclusions}

Strong antibacterial and antifungal activity and cell lysis are typical biological effects of lipopeptaibiotics [41,42]. In most cases, their biological activities are believed to be due to their membrane-modifying properties and ability to form transmembrane voltage-dependent channels or to cause destabilization or leakage of membrane lipid bilayers. Therefore, production of sphaerostibellins by $S$. toxica is consistent with the chemical behavior of other mycoparasitic fungi of the Hypocreaceae. The incorporation of a C-terminal putrescine residue, an intermediate in fungal polyamine metabolism [43], represents a new variation in the family. Although the sphaerostilbellins displayed broad biological toxicity, their effect was more pronounced on the fungi tested, which might be correlated with their ecological role, and warrants further investigation of the precise mechanism of their antifungal activity. In conclusion, the strategy of screening novel fungal species of mycoparasitic Hypocreaceae [19], e.g., S. toxica, has led to the discovery of two novel and potent antimicrobial peptaibiotics with the primary amine putrescine at the C-terminal end.

Supplementary Materials: The following are available online at http://www.mdpi.com/2218-273X/10/10/1371/s1, Figure S1: Zone of inhibition assay of extracts from strain TTI-0467 cultured in five different media against $C$. neoformans at $37^{\circ} \mathrm{C}$. See Methods for media formulations; Figure S2. Zone of inhibition assay of extracts from strain DPL-12808 cultured in five different media against C. neoformans at $37^{\circ} \mathrm{C}$. See Methods for media formulations; Figure S3. Zone of inhibition assay of extracts of strain TTI-1079 cultured in five different media against $C$. neoformans at $37^{\circ} \mathrm{C}$. See Methods for media formulations; Figure S4. LC-MS of peaks 1-4 after semi-preparative HPLC isolation, highlighting the interconversion of peaks 1-3 and 2-4; Figure S5. ${ }^{1} \mathrm{H}$ NMR spectrum of peaks 1-4 (500 MHz, CD 3 OD); Figure S6. ${ }^{1} \mathrm{H}$ NMR spectrum of $1\left(500 \mathrm{MHz}\right.$, DMSO- $\left.d_{6}\right)$; Figure S7. ${ }^{13} \mathrm{C}$ NMR spectrum of $1\left(125 \mathrm{MHz}, \mathrm{DMSO}-d_{6}\right)$; Figure S8. COSY spectrum of 1 (500 MHz, DMSO- $\left.d_{6}\right)$; Figure S9. HSQC spectrum of 1 (500 MHz, DMSO- $d_{6}$ ); Figure S10. HMBC spectrum of 1 (500 MHz, DMSO- $d_{6}$ ); Figure S11. ROESY spectrum of $1\left(500 \mathrm{MHz}, \mathrm{DMSO}-d_{6}\right)$; Figure S12. ${ }^{1} \mathrm{H}$ NMR spectrum of $2\left(500 \mathrm{MHz}, \mathrm{DMSO}-d_{6}\right)$; Figure S13. ${ }^{13} \mathrm{C}$ NMR spectrum of 2 (125 MHz, DMSO- $\left.d_{6}\right)$; Figure S14. COSY spectrum of 2 (500 MHz, DMSO- $\left.d_{6}\right)$; Figure S15. HSQC spectrum of 2 ( $\left.500 \mathrm{MHz}, \mathrm{DMSO}-d_{6}\right)$; Figure S16. HMBC spectrum of 2 (500 MHz, DMSO- $\left.d_{6}\right)$; Figure S17. ROESY spectrum of 2 ( $500 \mathrm{MHz}$, DMSO- $\left.d_{6}\right)$; Figure S18. LCMS chromatograms obtained after sample derivatization with Marfey's reagent. (a) Putrescine standard; (b) Amino acid standards; (c) Compound 1 hydrolyzate; (d) Compound 2 hydrolyzate. X represents a side-product; Figure S19. ${ }^{1} \mathrm{H}$ NMR $\left(500 \mathrm{MHz}, \mathrm{CD}_{3} \mathrm{OD}\right)$ spectra of sphaerostilbellin A at different times. (a) 0 days; (b) 4 days; (c) 110 days.

Author Contributions: C.B.N., J.A.A., J.B.G. and G.F.B. contributed to acquisition, analysis, and interpretation of data for the work. All authors contributed to the design of the work, writing and revision of the final draft, and approved the submitted and final version. All authors have read and agreed to the published version of the manuscript.

Funding: This work was supported by the Kay and Ben Fortson Endowment (to GB) and by grants from the National Institutes of Health (R01 GM121458 and R01 AI074677).

Acknowledgments: Mass spectrometry work was supported in part by the Clinical and Translational Proteomics Service Center at the University of Texas Health Science Center. H. Van T. Cotter guided collection of fungi in Raleigh, North Carolina.

Conflicts of Interest: The authors declare no conflict of interest. 


\section{References}

1. Benedict, K.; Jackson, B.R.; Chiller, T.; Beer, K.D. Estimation of direct healthcare costs of fungal diseases in the United States. Clin. Infect. Dis. 2018, 68, 1791-1797. [CrossRef] [PubMed]

2. Rajasingham, R.; Smith, R.M.; Park, B.J.; Jarvis, J.N.; Govender, N.P.; Chiller, T.M.; Denning, D.W.; Loyse, A.; Boulware, D.R. Global burden of disease of HIV-associated cryptococcal meningitis: An updated analysis. Lancet Infect. Dis. 2017, 17, 873-881. [CrossRef]

3. Brown, G.D.; Denning, D.W.; Gow, N.A.R.; Levitz, S.M.; Netea, M.G.; White, T.C. Hidden killers: Human fungal infections. Sci. Transl. Med. 2012, 4, 165rv113. [CrossRef] [PubMed]

4. Perfect, J.R. The antifungal pipeline: A reality check. Nat. Rev. Drug Discov. 2017, 16, 603-616. [CrossRef]

5. Van Daele, R.; Spriet, I.; Wauters, J.; Maertens, J.; Mercier, T.; Van Hecke, S.; Bruggemann, R. Antifungal drugs: What brings the future? Med. Mycol. 2019, 57, S328-S343. [CrossRef]

6. Xu, L.; Li, Y.; Biggins, J.B.; Bowman, B.R.; Verdine, G.L.; Gloer, J.B.; Alspaugh, J.A.; Bills, G.F. Identification of cyclosporin $\mathrm{C}$ from Amphichorda felina using a Cryptococcus neoformans differential temperature sensitivity assay. Appl. Microbiol. Biotechnol. 2018, 102, 2337-2350. [CrossRef]

7. Li, Y.; Yue, Q.; Jayanetti, D.R.; Swenson, D.C.; Bartholomeusz, G.A.; An, Z.; Gloer, J.B.; Bills, G.F. Anti-cryptococcus phenalenones and cyclic tetrapeptides from Auxarthron pseudauxarthron. J. Nat. Prod. 2017, 80, 2101-2109. [CrossRef]

8. Põldmaa, K.; Bills, G.; Lewis, D.P.; Tamm, H. Taxonomy of the Sphaerostilbella broomeana-group (Hypocreales, Ascomycota). Mycol. Prog. 2019, 18, 77-89. [CrossRef]

9. Gams, W.; Diederich, P.; Põldmaa, K. Chapter 17 - Fungicolous fungi. In Biodiversity of Fungi; Mueller, G.M., Bills, G.F., Foster, M.S., Eds.; Academic Press: Burlington, MA, USA, 2004; pp. 343-392.

10. Rossman, A.Y.; Samuels, G.J.; Rogerson, C.T.; Lowen, R. Genera of Bionectriaceae, Hypocreaceae and Nectriaceae (Hypocreales, Ascomycetes). Stud. Mycol. 1999, 42, 1-248.

11. Kredics, L.; Hatvani, L.; Naeimi, S.; Körmöczi, P.; Manczinger, L.; Vágvölgyi, C.; Druzhinina, I. Chapter 1 - Biodiversity of the genus Hypocrea/Trichoderma in different habitats. In Biotechnology and Biology of Trichoderma; Gupta, V.K., Schmoll, M., Herrera-Estrella, A., Upadhyay, R.S., Druzhinina, I., Tuohy, M.G., Eds.; Elsevier: Amsterdam, The Netherlands, 2014; pp. 3-24.

12. Dhodary, B.; Schilg, M.; Wirth, R.; Spiteller, D. Secondary metabolites from Escovopsis weberi and their role in attacking the garden fungus of leaf-cutting ants. Chem. Eur. J. 2018, 24, 4445-4452. [CrossRef]

13. Nair, M.S.R.; Carey, S.T.; James, J.C. Metabolites of pyrenomycetes. XIV. Structure and partial stereochemistry of the antibiotic macrolides hypothemycin and dihydrohypothemycin. Tetrahedron 1981, 37, 2445-2449. [CrossRef]

14. Röhrich, C.R.; Jaklitsch, W.M.; Voglmayr, H.; Iversen, A.; Vilcinskas, A.; Nielsen, K.F.; Thrane, U.; von Döhren, H.; Brückner, H.; Degenkolb, T. Front line defenders of the ecological niche! Screening the structural diversity of peptaibiotics from saprotrophic and fungicolous Trichoderma/Hypocrea species. Fungal Divers. 2014, 69, 117-146. [CrossRef] [PubMed]

15. Li, D.; Sossah, F.L.; Sun, L.; Fu, Y.; Li, Y. Genome analysis of Hypomyces perniciosus, the causal agent of wet bubble disease of button mushroom (Agaricus bisporus). Genes 2019, 10, 417. [CrossRef]

16. Degenkolb, T.; Kirschbaum, J.; Brückner, H. New sequences, constituents, and producers of peptaibiotics: An updated review. Chem. Biodivers. 2007, 4, 1052-1067. [CrossRef] [PubMed]

17. Neumann, N.K.N.; Stoppacher, N.; Zeilinger, S.; Degenkolb, T.; Brückner, H.; Schuhmacher, R. The peptaibiotics database-A comprehensive online resource. Chem. Biodivers. 2015, 12, 743-751. [CrossRef] [PubMed]

18. Degenkolb, T.; von Döhren, H.; Fog Nielsen, K.; Samuels, G.J.; Brückner, H. Recent advances and future prospects in peptaibiotics, hydrophobin, and mycotoxin sesearch, and their importance for chemotaxonomy of Trichoderma and Hypocrea. Chem. Biodivers. 2008, 5, 671-680. [CrossRef] [PubMed]

19. Degenkolb, T.; Berg, A.; Gams, W.; Schlegel, B.; Grafe, U. The occurrence of peptaibols and structurally related peptaibiotics in fungi and their mass spectrometric identification via diagnostic fragment ions. J. Pept. Sci. 2003, 9, 666-678. [CrossRef] [PubMed]

20. Bills, G.F.; Dombrowski, A.W.; Goetz, M.A. The "FERMEX" method for metabolite-enriched fungal extracts. Meth. Mol. Biol. 2012, 944, 79-96. 
21. Ayers, S.; Ehrmann, B.M.; Adcock, A.F.; Kroll, D.J.; Carcache de Blanco, E.J.; Shen, Q.; Swanson, S.M.; Falkinham III, J.O.; Wani, M.C.; Mitchell, S.M.; et al. Peptaibols from two unidentified fungi of the order Hypocreales with cytotoxic, antibiotic, and anthelmintic activities. J. Pept. Sci. 2012, 18, 500-510. [CrossRef]

22. Alexander, B.D. Reference Method for Broth Dilution Antifungal Susceptibility Testing of Yeasts. Approved Standard M27-A4, 4th ed.; Clinical and Laboratory Standards Institute: Wayne, PA, USA, 2017.

23. Samantaray, S.; Correia, J.N.; Garelnabi, M.; Voelz, K.; May, R.C.; Hall, R.A. Novel cell-based in vitro screen to identify small-molecule inhibitors against intracellular replication of Cryptococcus neoformans in macrophages. Int. J. Antimicrobiol. Agents 2016, 48, 69-77. [CrossRef]

24. Flissi, A.; Ricart, E.; Campart, C.; Chevalier, M.; Dufresne, Y.; Michalik, J.; Jacques, P.; Flahaut, C.; Lisacek, F.; Leclère, V.; et al. Norine: Update of the nonribosomal peptide resource. Nucl. Acid. Res. 2019, 48, D465-D469.

25. Whitmore, L.; Wallace, B.A. The peptaibol database: A database for sequences and structures of naturally occurring peptaibols. Nucl. Acid. Res. 2004, 32, D593-D594. [CrossRef] [PubMed]

26. Hegde, V.R.; Silver, J.; Patel, M.; Gullo, V.P.; Yarborough, R.; Huang, E.; Das, P.R.; Puar, M.S.; DiDomenico, B.J.; Loebenberg, D. Novel fungal metabolites as cell wall active antifungals: Fermentation, isolation, physico-chemical properties, structure and biological activity. J. Antibiotics 2001, 54, 74-83. [CrossRef]

27. Krasnoff, S.B.; Reátegui, R.F.; Wagenaar, M.M.; Gloer, J.B.; Gibson, D.M. Cicadapeptins I and II: New Aib-containing peptides from the entomopathogenic fungus Cordyceps heteropoda. J. Nat. Prod. 2005, 68, 50-55. [CrossRef] [PubMed]

28. Brückner, H.; Fox, S.; Degenkolb, T. Sequences of acretocins, peptaibiotics containing the rare 1-aminocyclopropanecarboxylic Aacid, from Acremonium crotocinigenum CBS 217.70. Chem. Biodivers. 2019, 16, e1900276. [CrossRef]

29. Du, L.; Risinger, A.L.; Mitchell, C.A.; You, J.; Stamps, B.W.; Pan, N.; King, J.B.; Bopassa, J.C.; Judge, S.I.V.; Yang, Z.; et al. Unique amalgamation of primary and secondary structural elements transform peptaibols into potent bioactive cell-penetrating peptides. Proc. Nat. Acad. Sci. USA 2017, 114, E8957-E8966. [CrossRef]

30. Vemula, H.; Kitase, Y.; Ayon, N.J.; Bonewald, L.; Gutheil, W.G. Gaussian and linear deconvolution of LC-MS/MS chromatograms of the eight aminobutyric acid isomers. Anal. Biochem. 2017, 516, 75-85. [CrossRef]

31. Ayon, N.J.; Sharma, A.D.; Gutheil, W.G. LC-MS/MS-based separation and quantification of Marfey's reagent derivatized proteinogenic amino acid DL-stereoisomers. J. Amer. Soc. Mass Spectrom. 2019, 30, 448-458. [CrossRef]

32. Ikuina, Y.; Bando, C.; Yoshida, M.; Yano, H.; Saitoh, Y. MS-681a, b, c and d, new inhibitors of myosin light chain kinase from Myrothecium sp. II. Physico-chemical properties and structure elucidation. J. Antibiotics 1997, 50, 998-1006. [CrossRef]

33. Christner, C.; Zerlin, M.; Gräfe, U.; Heinze, S.; Küllertz, G.; Fischer, G. Lipohexin, a new inhibitor of prolyl endopeptidase from Moeszia lindtneri (HKI-0054) and Paecilomyces sp. (HKI-0055; HKI-0096). II. Inhibitory activities and specificity. J. Antibiotics 1997, 50, 384-389. [CrossRef]

34. Heinze, S.; Ritzau, M.; Ihn, W.; Hülsmann, H.; Schlegel, B.; Dornberger, K.; Fleck, W.F.; Zerlin, M.; Christner, C.; Gräfe, U.; et al. Lipohexin, a new inhibitor of prolyl endopeptidase from Moeszia lindtneri (HKI-0054) and Paecilomyces sp. (HKI-0055; HKI-0096). I. Screening, isolation and structure elucidation. J. Antibiotics 1997, 50, 379-383. [CrossRef] [PubMed]

35. Hegde, V.R.; Silver, J.; Patel, M.; Gullo, V.P.; Puar, M.S.; Das, P.R.; Loebenberg, D. Novel fungal metabolites as cell wall active antifungals: Fermentation, isolation, physico-chemical properties, structure and biological activity. J. Antibiotics 2003, 56, 437-447. [CrossRef] [PubMed]

36. Stump, H.; Stahl, W.; Wink, J.; Markus, A.; Kogler, H.; Backhaus, J. Antifungal Peptides from Scleroderma Texense. U.S. Patent 6,221,844, 2 June 2001.

37. Pierson, N.A.; Chen, L.; Russell, D.H.; Clemmer, D.E. Cis-Trans isomerizations of proline residues are key to bradykinin conformations. J. Amer. Chem. Soc. 2013, 135, 3186-3192. [CrossRef] [PubMed]

38. Glover, M.S.; Shi, L.; Fuller, D.R.; Arnold, R.J.; Radivojac, P.; Clemmer, D.E. On the split personality of penultimate proline. J. Amer. Soc. Mass Spectrom. 2015, 26, 444-452. [CrossRef] [PubMed]

39. Siebler, C.; Maryasin, B.; Kuemin, M.; Erdmann, R.S.; Rigling, C.; Grünenfelder, C.; Ochsenfeld, C.; Wennemers, H. Importance of dipole moments and ambient polarity for the conformation of Xaa-Pro moieties-A combined experimental and theoretical study. Chem. Sci. 2015, 6, 6725-6730. [CrossRef] 
40. Loureiro, A.; Pais, C.; Sampaio, P. Relevance of macrophage extracellular traps in C. albicans killing. Front. Immunol. 2019, 10, 2767. [CrossRef]

41. Song, X.-Y.; Xie, B.-B.; Chen, X.-L.; Zhang, Y.-Z. Biosynthesis and molecular genetics of peptaibiotics-Fungal peptides containing alpha, alpha-dialkyl amino acids. In Biosynthesis and Molecular Genetics of Fungal Secondary Metabolites; Zeilinger, S., Martín, J.-F., García-Estrada, C., Eds.; Springer: New York, NY, USA, 2015; Volume 2, pp. 235-252.

42. Toniolo, C.; Crisma, M.; Formaggio, F.; Peggion, C.; Epand, R.F.; Epand, R.M. Lipopeptaibols, a novel family of membrane active, antimicrobial peptides. Cell. Mol. Life Sci. 2001, 58, 1179-1188. [CrossRef]

43. Valdés-Santiago, L.; Ruiz-Herrera, J. Stress and polyamine metabolism in fungi. Front. Chem. 2014, 1, 42. [CrossRef]

(C) 2020 by the authors. Licensee MDPI, Basel, Switzerland. This article is an open access article distributed under the terms and conditions of the Creative Commons Attribution (CC BY) license (http://creativecommons.org/licenses/by/4.0/). 